\title{
EFFECT OF INTENSIVE AND SEMI-INTENSIVE MANAGEMENT SYSTEMS ON GROWTH PERFORMANCE AND ECONOMICS OF MARECHA (Camelus dromedarius) CALVES REARED UNDER DESERT CONDITIONS
}

\author{
Asim Faraz ${ }^{1, *}$, Muhammad Younas ${ }^{2}$, Muhammad Lateef ${ }^{2}$ and Ghulam Muhammad ${ }^{3}$ \\ ${ }^{1}$ Department of Livestock and Poultry Production, Bahauddin Zakariya University, Multan, Pakistan; ${ }^{2}$ Institute of \\ Dairy Sciences, University of Agriculture, Faisalabad, Pakistan; ${ }^{3}$ Department of Clinical Medicine \\ and Surgery, University of Agriculture, Faisalabad, Pakistan \\ "Corresponding author's e-mail: drasimfaraz@bzu.edu.pk
}

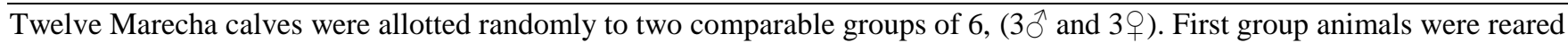
under intensive management system (IMS), fed concentrate @ $1 \mathrm{~kg} / \mathrm{h} / \mathrm{d}$ plus crop residues of gram (Cicer arientinum) adlibitum while in second group, calves were reared under semi-intensive management system (SIMS), sent for grazing 8 hours daily plus gram crop residues ad lib. Twice watering was done in both the groups. At end of trial mean body weight and ADG of male and female calves was significantly increased $(\mathrm{P}<0.05)$ in IMS $(80.83 \pm 2.7,77.83 \pm 2.7 \mathrm{~kg}$ and $0.674 \pm 0.02,0.649 \pm 0.02$ $\mathrm{kg} / \mathrm{d})$ than SIMS $(50.33 \pm 2.7,45.16 \pm 2.7 \mathrm{~kg}$ and $0.419 \pm 0.02,0.376 \pm 0.02 \mathrm{~kg} / \mathrm{d})$, respectively. Intake of crop residues varied $(\mathrm{P}<0.05)$ between groups $(6.93 \pm 0.45,6.37 \pm 0.45 ; 4.09 \pm 0.46,3.83 \pm 0.46 \mathrm{~kg} / \mathrm{d}$ in male and female calves, respectively). In behavioral preference the first in order was kari (Capparis spinosa), dhaman (Cenchrus ciliaris) and kikar (Acacia nilotica) among bushes, grasses and trees, respectively. Different biometrical parameters were significantly increased $(\mathrm{P}<0.05)$ in IMS as compared to SIMS. Regarding blood chemistry, the levels of hemoglobin, cholesterol, triglycerides, total protein, albumin, calcium and phosphorus were higher $(\mathrm{P}<0.05)$ in calves of IMS than SIMS while urea, creatinine and sugar were nonsignificantly different among groups of both management systems. The total feeding cost per calf for 120 days was higher in IMS than SIMS while the cost per kg body weight gain was less and economical in the former as compared to the latter group. Keywords: Dromedary camel, Cholistan desert, environment stress, ruminant's husbandry, growth performance, pastoral society.

\section{INTRODUCTION}

Camels are very well adapted to their native environment and can sustain life in hot and harsh deserts. The dromedary camel is a best source of meat and milk especially for those areas where production performance of other animals is adversely affected by the harsh environmental conditions. This mainly is due to its unique physiological characteristics that enable him to face higher temperatures, solar radiations, water scarcity, poor vegetation and rough terrains. It has less competition with any domestic specie regarding feed and performance. It can thrive on horny plants, thorny bushes, salty leaves and can browse variety of forages. In the absence of quality forages, camel can utilize poor quality forages with much more efficiency as it can retain fiber in its fore stomach for as long as 70 hours. According to Schwartz et al. (1992) in contrast with other ruminants, when it is fed with low protein forage it has the capacity and efficiency of reutilizing the urea for microbial protein synthesis. Due to these attributes camel is considered as the animal with unfathomed potential to meet the future dietary and medical needs of human beings (Faye and Esenov, 2005). However, in spite of all these attributes, the camel has for long remained a neglected animal.
In arid areas, camels constitute the most important source of meat. Mostly they are raised under traditional management systems as pastoralists are always moving in search of food and water over large areas for their camels (Omer et al., 2008). Camel is an indigenous genetic resource, it needs to be managed and preserved properly. It plays an indispensible role in the pastoral ecology. Different studies highlight its unique characteristics especially under stress environment. To meet the rapidly growing demands of exploding population, the strategic idea is to minimize the dependence on external food supply. There is need to recognize the place of camel in farm animals and to get increased output from indigenous natural resources that have not been exploited yet.

Camel husbandry system is in a state of flux as pastoralists are deviating from their traditional management system to semi-intensive and intensive management system. This rapidly changing scenario needs overall evaluation and there is an urgent need to undertake multi-disciplinary studies. Camel plays an indispensible role in the social life and economy of the people of arid and semi-arid areas in various regions of the world. Despite of its significant contribution to the livelihood of pastoral society who does not have any alternate mode of production system, the camel is one of the 
most neglected specie and very few attempts have been made so far to characterize its production potential and related parameters under natural conditions. Under traditional management system the camel productive traits are low so the traditional camel husbandry has no future (Bakheit et al., 2012). Mostly the research work on production potentials of camel has been done under traditional management systems without consideration of production systems (Iqbal et al., 2001).

Related measureable indices to body weight are very important for proper dozing of drugs and for assessing feed conversion performances. The study of blood constituents provides valuable information about the general health status of the animal (Omer et al., 2008). The current study was planned to explore the growth performance, feed intake, behavioral preference, biometry, blood constituents, hair mineral status and economics of Marecha calves rearing under intensive management system (IMS) and semiintensive management system (SIMS) under desert conditions.

\section{MATERIALS AND METHODS}

Study area and meteorological conditions: This study was conducted at Camel Breeding and Research Station (CBRS), Rakh Mahni, Tahsil Mankera, District Bhakkar. The CBRS is located in Thal area between $31^{\circ} 10^{\prime}$ and $32^{\circ} 22^{\prime}$ North Latitude and $70^{\circ} 47^{\prime}$ and $72^{\circ}$ East Longitude. Most of the area lies in the desert plain of the Thal. This area is included in the Agro Ecological Zone-III A and B (sandy desert area) having narrow strips of sand ridges and sand dunes. The climate is arid to semi-arid subtropical continental and mean monthly highest temperature goes up to $45.6^{\circ} \mathrm{C}$, while in winter it goes from 5.5 to $1.3^{\circ} \mathrm{C}$. Mean annual rainfall in the region ranges from 150-350 mm, increasing from South to North (Rahim et al., 2011).

Animal management: Before the start of experiment all the camel calves were marked for identification and dewormed to reduce the parasitic load. Calves were housed in semi-open pens throughout the trial. Initial body weights were recorded before shifting to the respective treatment groups and thereafter all the calves were weighed fortnightly before morning feeding on computerized weighing scale. The trial was of 120 days with 15 days as adaptation period.

Experimental animals and feeding plan: Twelve Marecha calves (Camelus dromedarius) around 330+30 days of age were allotted randomly to two comparable groups of 6 (3 $\bar{\sigma}$ and 3 o) having group weight of 1350 and $1340 \mathrm{~kg}$, respectively. The groups were composed on homobreed and heterosex calves. Water was provided twice a day in both the systems. The animals in the first group were fed concentrate @ $1 \mathrm{~kg} / \mathrm{h} / \mathrm{d}$ along with crop residues of gram (Cicer arientinum) round the clock, considered as IMS. The DM, CP, TDN, NDF and ADF of concentrate were 90.32, 18, 66, 29 and $14.41 \%$ while ME was $2.41 \mathrm{Mcal} / \mathrm{kg} \mathrm{DM}$, respectively. In second group all animals were sent for grazing/browsing daily for about 8 hours $(8-16 \mathrm{hr})$ while rest of the time were stall-fed with the gram crop residues $a d l i b$ and considered as SIMS.

Data collection: The growth rate and feed intake of calves were calculated. The average dry matter values of feed were measured and the dry matter intake (DMI) was determined. The choice of vegetation (grazing duration) was observed and the data was coded on a five point scale refers to the choice among bushes, grasses, trees (Bhakat et al., 2008). Feed intake of different grazing/browsing species of camel calves under SIMS was estimated by behavioral method (Wilson, 1998) and by using NDF values in the formula (Schroeder, 2013).

The biometrical parameters were recorded fortnightly with the help of measuring tape before morning feeding (Bhakat et al., 2008). These parameters were body length, chest and abdominal girth, shoulder height, hump circumference (horizontal and vertical), neck length, leg length (fore and hind), foot pad length and width (fore and hind). Towards the end of experiment, blood samples were collected from all calves for hematological analysis by jugular puncture in two sets. One contained EDTA as anticoagulant and the other without EDTA for serum separation.

Laboratory analysis: The concentrate, crop residues and herbage samples of the grazing/browsing material were analyzed for percent dry matter, crude protein, crude fiber, ether extract and ash (AOAC, 1990). Neutral detergent fiber (NDF) and acid detergent fiber (ADF) was also determined (Van Soest et al., 1991).

The blood samples were studied for hematological and biochemical analyses. Hemoglobin $(\mathrm{Hb})$ in blood sample while cholesterol, triglyceride, urea, total protein and albumin in serum samples were estimated by using standard kits (Spinreact, Spain) in hematology analyzer (BC 2300, Mindray Germany) and biochemistry analyzer (DL 9000, Italy), respectively. Blood samples were digested for mineral analyses. Calcium and phosphorus concentrations in blood were determined by atomic absorption spectrophotometer (AOAC, 1990). The Economics was calculated by considering the cost of feeding.

Statistical analysis: Data collected on different parameters were analyzed statistically by using Fisher's analysis of variance technique having $2 \times 2$ factorial arrangements of treatments under CRD using GLM of SPSS software (SPSS, 2008). Tukey's test at 0.05 levels of significance was used to compare the differences among the treatment means (Steel $e t$ al., 1997).

\section{RESULTS}

Growth rate: The calves of similar weight and size were selected in both management systems for this study. After 120 
days of trial period overall weight gain and daily weight gain (growth rate) was $80.83,77.83$ and $50.33,45.16 \mathrm{~kg}$ and 0.674 , 0.649 and $0.419,0.376 \mathrm{~kg} / \mathrm{d}$ in male and female calves reared under IMS and SIMS, respectively (Table 1). The values of fortnightly body weight gain of male and female calves in both systems are presented in Figure 1.

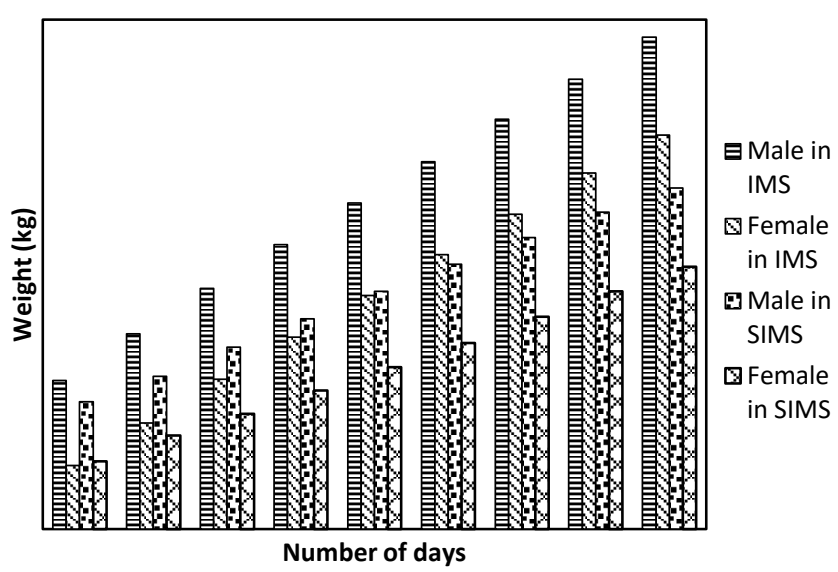

Figure 1.Comparison of male and female calves' fortnightly body weight gain in IMS and SIMS.
Feed intake: Average daily intake was found to be significantly varied $(\mathrm{P}<0.05)$ among calf groups between IMS and SIMS $(6.93 \pm 0.45,6.37 \pm 0.45$ and $4.09 \pm 0.46,3.83 \pm 0.46$ $\mathrm{kg}$ ) in male and female calves, respectively (Table 2).

Grazing preference and behavioral feed intake: The forage species like kikar (Acacia nilotica), phulai (Acacia modesta), beri (Ziziphus mauritiana), siras (Albizia labbek), jand (Prosopis cineraria), khagal (Tamarix aphylla), dhaman (Cenchrus ciliaris), persain (Suaeda fruticosa), khawi (Cymbopogon schoenanthus), kali bui (Kochia indica), bhakra (Tribulus terrestris), kari (Capparis spinosa), laana (Haloxylon salincornicum), phog (Calligonam polygonoides), karir (Capparis decidua) and khar laana (Haloxylon recurvum) were available species for browsing/grazing for calves. While in present study regarding grazing preference kari (Capparis spinosa), dhaman (Cenchrus ciliaris) and kikar (Acacia nilotica) got the first score (80-100\% preference) among bushes, grasses and trees, respectively (Table 3). Feed intake of different grazing/browsing species of camel calves estimated by behavioral method and by using NDF values in the formula under SIMS are presented in Supplementary Table 1 while proximate analysis of crop residues and different

Table 1. Overall weight gain $(\mathrm{kg})$ and growth rate $(\mathrm{kg} / \mathrm{d})$ of male and female camel calves in IMS and SIMS.

\begin{tabular}{lcccc}
\hline Parameter & \multicolumn{2}{c}{ IMS } & \multicolumn{2}{c}{ SIMS } \\
\cline { 2 - 5 } & Male & Female & Male & Female \\
\hline Growth at 30 d & $21.67 \pm 0.97^{\mathrm{a}}$ & $20.33 \pm 0.97^{\mathrm{a}}$ & $12.83 \pm 0.97^{\mathrm{b}}$ & $10.50 \pm 0.97^{\mathrm{b}}$ \\
Growth at 60 d & $20.17 \pm 0.61^{\mathrm{a}}$ & $19.67 \pm 0.61^{\mathrm{a}}$ & $13.17 \pm 0.61^{\mathrm{b}}$ & $11.00 \pm 0.61^{\mathrm{b}}$ \\
Growth at 90 d & $19.67 \pm 0.68^{\mathrm{a}}$ & $19.17 \pm 0.68^{\mathrm{a}}$ & $12.67 \pm 0.68^{\mathrm{b}}$ & $11.83 \pm 0.68^{\mathrm{b}}$ \\
Growth at 120 d & $19.33 \pm 0.63^{\mathrm{a}}$ & $18.67 \pm 0.63^{\mathrm{a}}$ & $11.67 \pm 0.63^{\mathrm{b}}$ & $11.83 \pm 0.63^{\mathrm{b}}$ \\
Overall weight gain & $80.83 \pm 2.70^{\mathrm{a}}$ & $77.83 \pm 2.70^{\mathrm{a}}$ & $50.33 \pm 2.70^{\mathrm{b}}$ & $45.16 \pm 2.70^{\mathrm{b}}$ \\
Daily weight gain & $0.67 \pm 0.02^{\mathrm{a}}$ & $0.65 \pm 0.02^{\mathrm{a}}$ & $0.42 \pm 0.02^{\mathrm{b}}$ & $0.38 \pm 0.02^{\mathrm{b}}$ \\
\hline
\end{tabular}

Table 2. Average male and female camel calves' intake of crop residues (kg) on DM basis in IMS and SIMS.

\begin{tabular}{lcccc}
\hline Parameter & \multicolumn{2}{c}{ IMS } & \multicolumn{2}{c}{ SIMS } \\
\cline { 2 - 5 } & Male & Female & Male & Female \\
\hline ADI in 30 d & $6.50 \pm 0.44^{\mathrm{a}}$ & $5.92 \pm 0.44^{\mathrm{a}}$ & $3.90 \pm 0.44^{\mathrm{b}}$ & $3.65 \pm 0.44^{\mathrm{b}}$ \\
ADI in 60 d & $6.98 \pm 0.45^{\mathrm{a}}$ & $6.40 \pm 0.45^{\mathrm{a}}$ & $4.10 \pm 0.45^{\mathrm{b}}$ & $3.82 \pm 0.45^{\mathrm{b}}$ \\
ADI in 90 d & $7.45 \pm 0.46^{\mathrm{a}}$ & $6.83 \pm 0.46^{\mathrm{a}}$ & $4.30 \pm 0.46^{\mathrm{b}}$ & $4.05 \pm 0.46^{\mathrm{b}}$ \\
ADI in 120 d & $7.93 \pm 0.45^{\mathrm{a}}$ & $7.35 \pm 0.45^{\mathrm{a}}$ & $4.50 \pm 0.45^{\mathrm{b}}$ & $4.27 \pm 0.45^{\mathrm{b}}$ \\
Daily feed intake/animal & $6.93 \pm 0.45^{\mathrm{a}}$ & $6.37 \pm 0.45^{\mathrm{a}}$ & $4.09 \pm 0.46^{\mathrm{b}}$ & $3.83 \pm 0.46^{\mathrm{b}}$ \\
\hline
\end{tabular}

Table 3. Grazing preference of bushes, grasses and trees by camel calves under SIMS.

\begin{tabular}{lllll}
\hline $\begin{array}{l}\text { Score } \\
\text { Preference } \\
\text { percentage }\end{array}$ & Bushes & Grasses & Trees \\
\hline 1 & $80-100$ & Kari (Capparis spinosa) & Dhaman (Cenchrus ciliaris) & Kikar (Acacia nilotica) \\
2 & $60-79$ & Laana (Haloxylon salincornicum) & Persain (Suaeda fruticosa) & Phulai (Acacia modesta) \\
3 & $40-59$ & Phog (Calligonam polygonoides) & Khawi(Cymbopogon & Beri leaves (Ziziphus \\
& & & schoenanthus) & mauritiana) \\
4 & $20-39$ & Karir (Capparis decidua) & Kali Bui (Kochia indica) & Siras (Albizia labbek) \\
5 & $01-19$ & KharLaana (Haloxylon recurvum) & Bhakra (Tribulus terrestris) & Jand (Prosopis cineraria) and \\
& & & & Khagal (Tamarix aphylla) \\
\hline
\end{tabular}


Faraz, Younas, Lateef \& Muhammad

Supplementary Table 1. Feed intake of different grazing/browsing species by camel calves under SIMS.

\begin{tabular}{llcccc}
\hline Category & Species & No. of Bites/hr & Bite Weight (g) & DMI (g/hr) & DMI (\%) \\
\hline Bushes & Kari (Capparis spinosa) & 270 & 2.5 & 675 & 2.32 \\
& Laana (Haloxylon salincornicum) & 260 & 2.5 & 650 & 2.34 \\
& Phog (Calligonam polygonoides) & 210 & 3.0 & 630 & 2.42 \\
& Karir (Capparis decidua) & 200 & 3.0 & 600 & 2.24 \\
& KharLaana (Haloxylon recurvum) & 240 & 2.8 & 672 & 2.44 \\
Grasses & Dhaman (Cenchrus ciliaris) & 240 & 4.5 & 1080 & 3.11 \\
& Persain(Suaeda fruticosa) & 180 & 3.0 & 540 & 2.46 \\
& Khawi(Cymbopogon schoenanthus) & 90 & 3.5 & 315 & 1.93 \\
& Kali Bui (Kochia indica) & 204 & 3.5 & 714 & 2.05 \\
\multirow{5}{*}{ Trees } & Bhakra (Tribulus terrestris) & 160 & 2.5 & 400 & 2.57 \\
& Kikar (Acacia nilotica) & 220 & 2.8 & 616 & 2.16 \\
& Phulai (Acacia modesta) & 165 & 1.3 & 215 & 2.57 \\
& Beri leaves (Ziziphus mauritiana) & 264 & 1.7 & 449 & 2.48 \\
& Siras (Albizia labbek) & 210 & 2.5 & 525 & 2.79 \\
& Jand (Prosopis cineraria) & 228 & 3.5 & 798 & 2.53 \\
& Khagal (Tamarix aphylla) & 210 & 3.0 & 610 & 2.83 \\
\hline
\end{tabular}

Supplementary Table 2. Proximate analysis (\%) of crop residue and different grazing/browsing species.

\begin{tabular}{lcrrrrrr}
\hline Feed/Forage Species & DM & CP & EE & CF & NDF & ADF & Crude Ash \\
\hline Gram Straw (Cicer arientinum) & 93.53 & 9.72 & 2.60 & 44.40 & 68.70 & 47.60 & 7.83 \\
Kikar (Acacia nilotica) & 28.50 & 16.71 & 1.79 & 25.08 & 55.40 & 25.40 & 5.94 \\
Phulai (Acacia modesta) & 53.40 & 13.23 & 2.21 & 35.40 & 46.60 & 28.78 & 6.94 \\
Beri leaves (Ziziphus mauritiana) & 40.20 & 15.52 & 5.77 & 28.02 & 48.30 & 26.90 & 8.48 \\
Siras (Albizia labbek) & 37.30 & 16.17 & 6.58 & 27.25 & 43.00 & 29.00 & 16.33 \\
Jand (Prosopis cineraria) & 46.15 & 16.86 & 6.52 & 19.14 & 47.50 & 29.00 & 4.95 \\
Khagal (Tamarix aphylla) & 31.90 & 12.81 & 3.25 & 17.32 & 42.40 & 31.60 & 13.03 \\
Dhaman (Cenchrus ciliaris) & 31.90 & 14.69 & 3.94 & 26.51 & 38.53 & 18.15 & 15.71 \\
Persain (Suaeda fruticosa) & 30.30 & 10.57 & 5.52 & 33.14 & 48.70 & 27.60 & 7.54 \\
Khawi(Cymbopogon schoenanthus) & 34.60 & 9.53 & 2.01 & 35.67 & 62.10 & 43.50 & 7.14 \\
Kali Bui (Kochia indica) & 33.78 & 10.80 & 4.91 & 27.61 & 58.60 & 39.76 & 13.32 \\
Bhakra (Tribulus terrestris) & 32.10 & 8.76 & 4.58 & 32.63 & 46.70 & 35.40 & 9.64 \\
Kari (Capparis spinosa) & 36.70 & 17.84 & 1.18 & 30.75 & 51.80 & 33.50 & 6.97 \\
Laana (Haloxylon salincornicum) & 34.20 & 15.85 & 3.09 & 32.33 & 51.34 & 37.50 & 11.93 \\
Phog (Calligonam polygonoides) & 34.70 & 8.95 & 4.82 & 23.42 & 49.60 & 31.90 & 8.76 \\
Karir (Capparis decidua) & 49.40 & 16.75 & 1.52 & 24.64 & 53.60 & 37.80 & 14.76 \\
KharLaana (Haloxylon recurvum) & 47.90 & 12.36 & 3.32 & 24.95 & 49.20 & 31.30 & 12.15 \\
\hline
\end{tabular}

grazing/browsing species are given in Supplementary Table 2.

Biometrical parameters: The biometrical parameters of camel calves like shoulder height, chest girth, hump circumference (horizontal and vertical), neck length, body length, leg length (fore and hind), foot pad length and width (fore and hind) were taken in this study are presented in Table 4 . The measurements taken at start $(0 \mathrm{~d})$ were compared with those taken at the termination of the experiment (120 d). The parameters like shoulder height, hump circumference (horizontal), leg length (fore \& hind) and foot pad length and width (fore \& hind) were significantly different $(\mathrm{P}<0.05)$ among male and female calves between two systems. This proves that there was a complete skeletal growth which was not only by adipose accumulation. Non-significant differences $(\mathrm{P}>0.05)$ were found regarding hump girth measurements which proves that adipose accumulation was not so different among calves as the growth was mainly due to the increase in size of the skeletal structure. While chest girth, hump circumference (vertical), neck length and body length measurements were more or less significant $(\mathrm{P}<0.05)$ among male and female calves. Significant difference in biometrical parameters is a clear indicative of increasing 
Management of camel calves

Table 4. Body measurements $(\mathrm{cm})$ of male and female camel calves in IMS and SIMS.

\begin{tabular}{lcccc}
\hline Parameter & \multicolumn{2}{c}{ IMS } & \multicolumn{2}{c}{ SIMS } \\
\cline { 2 - 5 } & Male & Female & Male & Female \\
\hline Shoulder Height & $15.83 \pm 0.83^{\mathrm{a}}$ & $15.00 \pm 0.83^{\mathrm{a}}$ & $7.50 \pm 0.83^{\mathrm{b}}$ & $6.25 \pm 0.83^{\mathrm{b}}$ \\
Chest Girth & $21.75 \pm 2.16^{\mathrm{a}}$ & $20.00 \pm 2.16^{\mathrm{a}}$ & $18.33 \pm 2.16^{\mathrm{ab}}$ & $12.08 \pm 2.16^{\mathrm{b}}$ \\
Hump Girth & $20.83 \pm 4.31$ & $15.42 \pm 4.31$ & $12.92 \pm 4.31$ & $11.67 \pm 4.31$ \\
Hump Circumference (H) & $27.92 \pm 0.88^{\mathrm{a}}$ & $22.50 \pm 0.88^{\mathrm{b}}$ & $17.09 \pm 0.88^{\mathrm{c}}$ & $14.58 \pm 0.88^{\mathrm{cd}}$ \\
Hump Circumference (V) & $20.83 \pm 1.30^{\mathrm{a}}$ & $17.08 \pm 1.30^{\mathrm{ab}}$ & $13.33 \pm 1.30^{\mathrm{bcd}}$ & $10.00 \pm 1.30^{\mathrm{cd}}$ \\
Neck Length & $20.42 \pm 1.49^{\mathrm{a}}$ & $16.67 \pm 1.49^{\mathrm{ab}}$ & $15.00 \pm 1.49^{\mathrm{bc}}$ & $13.34 \pm 1.49^{\mathrm{b}}$ \\
Body Length & $22.92 \pm 1.08^{\mathrm{a}}$ & $21.67 \pm 1.08^{\mathrm{ab}}$ & $18.33 \pm 1.08^{\mathrm{bc}}$ & $15.00 \pm 1.08^{\mathrm{c}}$ \\
Leg Length (F) & $21.25 \pm 1.40^{\mathrm{a}}$ & $19.67 \pm 1.40^{\mathrm{a}}$ & $15.08 \pm 1.40^{\mathrm{b}}$ & $13.50 \pm 1.40^{\mathrm{b}}$ \\
Leg Length (H) & $21.25 \pm 1.36^{\mathrm{a}}$ & $17.50 \pm 1.36^{\mathrm{a}}$ & $16.67 \pm 1.36^{\mathrm{b}}$ & $15.00 \pm 1.36^{\mathrm{b}}$ \\
Foot Pad Length (F) & $9.42 \pm 0.27^{\mathrm{a}}$ & $8.42 \pm 0.27^{\mathrm{b}}$ & $6.67 \pm 0.27^{\mathrm{c}}$ & $5.83 \pm 0.27^{\mathrm{cd}}$ \\
Foot Pad Width (F) & $9.17 \pm 0.45^{\mathrm{a}}$ & $7.58 \pm 0.45^{\mathrm{b}}$ & $5.83 \pm 0.45^{\mathrm{c}}$ & $4.83 \pm 0.45^{\mathrm{cd}}$ \\
Foot Pad Length (H) & $7.83 \pm 0.23^{\mathrm{a}}$ & $7.17 \pm 0.23^{\mathrm{a}}$ & $5.50 \pm 0.23^{\mathrm{b}}$ & $4.67 \pm 0.23^{\mathrm{c}}$ \\
Foot Pad Width (H) & $7.08 \pm 0.35^{\mathrm{a}}$ & $6.17 \pm 0.35^{\mathrm{a}}$ & $4.67 \pm 0.35^{\mathrm{b}}$ & $4.00 \pm 0.35^{\mathrm{b}}$ \\
\hline
\end{tabular}

Table 5. Blood biochemicals of male and female camel calves in IMS and SIMS.

\begin{tabular}{|c|c|c|c|c|}
\hline \multirow[t]{2}{*}{ Parameter } & \multicolumn{2}{|c|}{ IMS } & \multicolumn{2}{|c|}{ SIMS } \\
\hline & Male & Female & Male & Female \\
\hline Hemoglobin $(\mathrm{g} / \mathrm{dL})$ & $16.60 \pm 0.23^{\mathrm{a}}$ & $15.93 \pm 0.23^{\mathrm{a}}$ & $14.73 \pm 0.23^{\mathrm{b}}$ & $14.13 \pm 0.23^{\mathrm{b}}$ \\
\hline Cholesterol (mg/dL) & $46.67+2.48^{\mathrm{a}}$ & $43.97 \pm 2.48^{\mathrm{ab}}$ & $38.30+2.48^{\mathrm{bc}}$ & $37.87+2.48^{\mathrm{b}}$ \\
\hline Triglycerides (mg/dL) & $38.67 \pm 1.92^{\mathrm{a}}$ & $36.00 \pm 1.92^{\mathrm{a}}$ & $20.67 \pm 1.92^{\mathrm{b}}$ & $17.67 \pm 1.92^{\mathrm{b}}$ \\
\hline Albumin $(\mathrm{g} / \mathrm{dL})$ & $1.53 \pm 0.07^{\mathrm{a}}$ & $1.47 \pm 0.07^{\mathrm{a}}$ & $1.37 \pm 0.07^{\mathrm{a}}$ & $1.23 \pm 0.07^{\mathrm{ab}}$ \\
\hline Total Protein (g/dL) & $6.53 \pm 0.17^{\mathrm{a}}$ & $6.36 \pm 0.17^{\mathrm{a}}$ & $5.30 \pm 0.17^{\mathrm{b}}$ & $5.03 \pm 0.17^{\mathrm{b}}$ \\
\hline Urea $(\mathrm{mg} / \mathrm{dL})$ & $35.40 \pm 4.48$ & $32.00 \pm 4.48$ & $36.33 \pm 4.48$ & $31.33 \pm 4.48$ \\
\hline Creatinine $(\mathrm{mg} / \mathrm{dL})$ & $1.40 \pm 0.13$ & $1.47 \pm 0.13$ & $1.37 \pm 0.13$ & $1.50 \pm 0.13$ \\
\hline Sugar $(\mathrm{mg} / \mathrm{dL})$ & $126.33 \pm 3.70$ & $130.67 \pm 3.70$ & $130.00 \pm 3.70$ & $136.33 \pm 3.70$ \\
\hline Calcium (mg/dL) & $9.13 \pm 0.43^{\mathrm{a}}$ & $7.30 \pm 0.43^{\mathrm{b}}$ & $7.00 \pm 0.43^{\mathrm{b}}$ & $6.4 \pm 0.43^{\mathrm{b}}$ \\
\hline Phosphorus (mg/dL) & $4.55+0.22^{\mathrm{a}}$ & $3.52+0.22^{b}$ & $3.45+0.22^{\mathrm{b}}$ & $3.2 \overline{3}+0.22^{b}$ \\
\hline
\end{tabular}

Table 6. Economic analysis of male and female camel calves in IMS and SIMS.

\begin{tabular}{lcccc}
\hline Costs & \multicolumn{2}{c}{ IMS } & \multicolumn{2}{c}{ SIMS } \\
\cline { 2 - 5 } & Male & Female & Male & Female \\
\hline Total feeding cost Rs./calf & $5725(\$ 55)$ & $5498(\$ 52)$ & $4989(\$ 48)$ & $4884(\$ 47)$ \\
Total feeding cost Rs./calf/d & $48(\$ 0.46)$ & $46(\$ 0.44)$ & $42(\$ 0.40)$ & $41(\$ 0.39)$ \\
Total cost Rs./kg gain & $71(\$ 0.68)$ & $70(\$ 0.67)$ & $99(\$ 0.94)$ & $108(\$ 1.03)$ \\
\hline
\end{tabular}

weight gain of calves in intensive management system than calves of semi intensive management system.

Blood parameters and serum biochemistry: The blood constituents like hemoglobin, cholesterol, triglycerides, albumin, total protein, urea, creatinine, sugar, calcium and phosphorus were studied in this experiment are presented in Table 5. The mean values for hemoglobin were found to be significant $(\mathrm{P}<0.05)$ as $16.60 \pm 0.23, \quad 15.93 \pm 0.23$ and $14.73 \pm 0.23,14.13 \pm 0.23 \mathrm{~g} / \mathrm{dL}$ for male and female camel calves in IMS and SIMS, respectively while for cholesterol as $46.67+2.48,43.97+2.48$ and $38.30+2.48,37.87+2.48 \mathrm{mg} / \mathrm{dL}$; triglycerides as $38.67+1.92,36.00+1.92$ and $20.67+1.92$, $17.67+1.92 \mathrm{mg} / \mathrm{dL}$; albumin as $1.53 \pm 0.07,1.47 \pm 0.07$ and $1.37 \pm 0.07,1.23 \pm 0.07 \mathrm{~g} / \mathrm{dL}$; total protein as $6.53 \pm 0.17$, $6.36 \pm 0.17$ and $5.30 \pm 0.17,5.03 \pm 0.17 \mathrm{~g} / \mathrm{dL}$; calcium as
$9.13 \pm 0.43, \quad 7.30 \pm 0.43$ and $7.00 \pm 0.43, \quad 6.4 \pm 0.43 \mathrm{mg} / \mathrm{dL}$; phosphorus as $4.55 \pm 0.22, \quad 3.52 \pm 0.22$ and $3.45 \pm 0.22$, $3.23 \pm 0.22 \mathrm{mg} / \mathrm{dL}$ found to be significant $(\mathrm{P}<0.05)$ for male and female calves in both the management systems, respectively. Non-significant values $(\mathrm{P}>0.05)$ for urea as $35.40+4.48,32.00+4.48$ and $36.33+4.48,31.33+4.48 \mathrm{mg} / \mathrm{dL}$; creatinine as $1.40 \pm 0.13,1.47 \pm 0.13$ and $1.37 \pm 0.13,1.50 \pm 0.13$ $\mathrm{mg} / \mathrm{dL}$; sugar as $126.33 \pm 3.70,130.67 \pm 3.70$ and $130.00 \pm 3.70$, $136.33 \pm 3.70 \mathrm{mg} / \mathrm{dL}$ for male and female calves in IMS and SIMS, respectively.

Economic analysis: Total feeding cost per calf in rupees was higher in male and female calves of IMS group as well as total feeding cost per calf per day was also higher in these calves while total cost per $\mathrm{kg}$ gain was quiet less in this group (Table 6). 


\section{DISCUSSION}

Growth rate: The average growth rate was significantly higher $(\mathrm{P}<0.05)$ in calves of IMS as compared to the calves of SIMS. These findings are in line with the findings of Bhakat et al. (2008) who studied the effect of management systems on growth performance of dromedary camel calves in India, they used 10 camel calves aged between 7-10 months old in their study and divided them randomly into two comparable groups of 5 each. The average initial body weight of both groups was almost similar. The groups were of hetero breed and hetero sex combinations, each group contained 3 Jaisalmeri, 1 Bikaneri, 1 Katchi breed and 4 males and 1 female. At end of the trial, average total gain was almost double in ISM than SISM group. The average growth rate was significantly higher in ISM (611 g/d) than SISM (319 g/d).

In present study, male calves attain higher weights in both the systems, may be due to the reason that more receptors are present on muscle cells for androgens that accelerates the growth (Hossner, 2005). These findings are supported by the findings of Knoess (1977) and Qureshi (1986) who reported average daily weight gain as $1.4 \mathrm{~kg}$ in male, $0.95 \mathrm{~kg}$ in female; $1.5 \mathrm{~kg}$ in male, $1 \mathrm{~kg}$ in female camel calves, respectively in Pakistan. Musavaya (2003) reported weight gain in calves as $0.41 \mathrm{~kg} / \mathrm{d}$ in males and $0.38 \mathrm{~kg} / \mathrm{d}$ in females while weight gain after the sexual maturity as $0.12 \mathrm{~kg} / \mathrm{d}$ in males and $0.06 \mathrm{~kg} / \mathrm{d}$ in females. Kurtu (2004) reported that mature male calves were heavier than female calves by $38 \%$. Indian scientists Sahani et al. (1998) reported average daily gain in 0-3 (0.63, $0.58)$; 3-6 (0.64, 0.62); 6-9 (0.37, 0.39); 9-12 (0.23, 0.23); 18 $24(0.16,0.20) ; 24-30(0.16,0.17)$ and $30-36$ months $(0.18$, $0.14) \mathrm{kg}$ in male and female calves, respectively. Male calves weighed more than females. Khanna et al. (2004) reported average daily gain (ADG) as 0.7 and $0.77 \mathrm{~kg}$ in Jaisalmeri and Bikaneri Indian camel breeds from birth to 3 months of age, respectively. However, no significant difference was found to be in male and female calves regarding their daily weight gain.

Current findings are in accordance with the findings of Saini et al. (2014) who also reported higher total and average daily gain $(\mathrm{kg})$ in stall fed pre-pubescent camels as compared to grazing group. In Sudan Mohamedain et al. (2015) studied growth performance in dromedary camels under two feeding regimen. First was zero browsing group (15 Darfuri \& 10 Butana) fed complete ration (sorghum $50 \%$, groundnut cake $15 \%$, wheat bran $5 \%$, molasses $10 \%$, dura husk $5 \%$, bagas $12 \%$, urea $2 \%$ and common salt $1 \%$ ) to provide ME @ 11 $\mathrm{MJ} / \mathrm{kg} \mathrm{DM}$ and $16 \% \mathrm{CP}$. Second was free browsing group with same breeds without any supplement. The trail was of 120 days with two weeks as adaptation period. The average total weight gain was almost double in zero browsing group $(96 \pm 17.3 \mathrm{~kg})$ than free browsing group $(42 \pm 19.5 \mathrm{~kg})$. ADG was $800 \mathrm{~g}$ in zero browsing group as compared to $350 \mathrm{~g}$ in free browsing group. While in present study, lower daily weight gain was observed in IMS due to the limited supply of concentrate.

Present findings are not in line with the findings of Bhakat et al. (2009) who reported that the average daily gain (g/d) differed significantly among two systems, being higher in SIMS as (325 and $476 \mathrm{~g} / \mathrm{d})$ than IMS as (278 and $331 \mathrm{~g} / \mathrm{d}$ ) with guar phalgati (Cyamopsis tetragonoloba) and moth chara (Phaseolus aconitifolius) feeding, respectively. Bakheit et al. (2012) reported significant differences in the mean daily

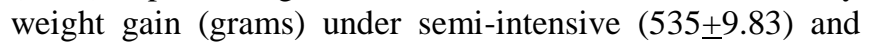
traditional management systems (TMS) (317 \pm 5.46$)$, respectively.

Feed intake: These findings are in line with the findings of Bhakat et al. (2008) who studied the effect of management systems on growth performance of Indian camel calves and reported that the crop residue intake was significantly varied between two groups, $5.53 \mathrm{vs.} 4.37 \mathrm{~kg} / \mathrm{calf} / \mathrm{d}$ in IMS and SIMS, respectively. Moreover, Saini et al. (2014) reported higher DMI $(\mathrm{kg} / \mathrm{d})$ in stall fed pre-pubescent camels as compared to grazing group.

However, present findings are not in accordance with the findings of Bhakat et al. (2009) who determined growth characteristics of Indian camel calves under IMS and SIMS, where they found non-significant intake by using Guar phalgati chara (Cyamopsis tetragonoloba) (6.02 vs. 5.14 $\mathrm{kg} / \mathrm{calf} / \mathrm{d}$ ) and significant with moth chara (Phaseolus aconitifolius) (7.91 vs. $6.24 \mathrm{~kg} / \mathrm{calf} / \mathrm{d})$, respectively. Furthermore, the current study findings are supported by the findings of Tandon et al. (1993) who reported that the dry fodder and water intake was positively correlated while the relationship between growth of weaned calves. Moreover, dry matter intake (DMI) was also found to be positively correlated in Indian camel calves (Singh et al., 2000).

Grazing preference and behavioral feed intake: Very few scientists have worked on specie preference for camel. Indian scientists Bhakat et al. (2008) reported that phog (Calligonum polygonoides), ganthia (Dactyloctenium aegypticum) and khejri (Prosopis cineraria) were of first order in behavioral preference among bushes, grasses and trees, respectively. While in present study regarding grazing preference kari (Capparis spinosa), dhaman (Cenchrus ciliaris) and kikar (Acacia nilotica) got the first score (80-100\% preference) among bushes, grasses and trees, respectively. This may be due to the reason that these species has higher CP contents that could be the choice for browsing by camel calves as their natural dietery preference. Iqbal et al. (2001) reported that major plant species which forms the diet makeup of camel are Acacia modesta, Olea ferruginea and Alhaji camelorum while likeness of Acacia modesta in adults is due to its higher crude protein contents.

Biometrical parameters: Very less work has been reported in the literature regarding biometry in camels. Indian scientists Bhakat et al. (2008) studied the effect of management system on growth performance of camel calves and reported 
biometrical parameters in their study as being higher in IMS than SIMS. Present findings are also in accordance with the findings of Saini et al. (2014) who found significant increase in body length and height of pre-pubescent stall fed camels than grazing camels under pastoral management in arid western Rajasthan.

Blood biochemicals: Hemoglobin was found to be higher in males as compared to the females may be due to the reason that testosterone affects on the kidneys to produce more erythropoietin that accelerates the erythropoiesis (Murphy, 2014). Cholesterol and triglycerides were also found higher in calves of higher growth rate (IMS) as the calves were in active metabolic state. Urea and creatinine are the indirect tests for the proper kidney functioning and excretion. Creatinine which is an anhydride of creatine phosphate results by the muscle synthesis, a routine product formed due to muscle metabolism and excreted on regular basis (Brar et al., 2000). While sugar level in camels was found to be higher than other animals and that could be the reason of reported higher lactic acid contents in the blood of camels (Osman and Al-Busadah, 2003). Being in active fattening condition the levels of total protein and albumins were also higher as the animals showed increased growth rate, moreover the serum electrolytes were also found to be higher as their ratio relates with the age factor being higher in early and growing age. The current findings are in accordance with the findings of Indian scientist Bhakat et al. (2008) who determined blood biochemicals in camel calves under different management systems and reported significant differences for triglycerides and total protein as $34.79 \pm 3.67,19.05 \pm 2.92 \mathrm{mg} / \mathrm{dL}$ and $6.28 \pm 0.26,4.67 \pm 0.40 \mathrm{~g} / \mathrm{dL}$ in camel calves in intensive and semi-intensive system of management, respectively while non-significant differences were found regarding urea, albumin, calcium and phosphorus in their study. Present findings regarding urea and sugar contents are not in line with the findings of Saini et al. (2014) who found significantly lower sugar and higher urea values in grazing pre-pubescent camels than stall fed group under pastoral management in arid western Rajasthan.

The findings of present study are not in agreement with the findings of Al-Busadah and Osman (2000) who determined hematological values in camels of Saudi Arabia and reported mean value for hemoglobin as $13.3 \pm 0.6,12 \pm 0.2$ and $10.1 \pm 0.8$ $\mathrm{g} / \mathrm{dL}$ in dry-adult, lactating and calves, respectively. Current results (IMS) are very close to the results of Osman and AlBusadah (2003) regarding some parameters who studied normal concentrations of serum biochemicals of she-camels in Saudi Arabia and determined glucose (134.4 \pm 11$)$,

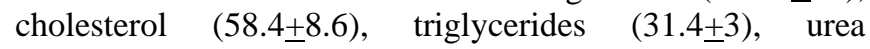
(49.8 \pm 5.5$)$, creatinine $(1.5 \pm 0.1) \mathrm{mg} / \mathrm{dL}$, total protein $(7.1 \pm 0.3)$ and albumin $(3.7 \pm 0.3) \mathrm{g} / \mathrm{dL}$.

Omer et al. (2008) studied hematological profile of Sudanese suckling camel calves to their lactating dams and reported significantly higher hemoglobin concentration in suckling calves as $11.42 \pm 1.20$ to their lactating dams as $10.69 \pm 0.62$ g/dL. Nagpal et al. (2012) determined serum profile of weaned Indian camel calves and reported glucose as $110.45 \pm 3.67,105.54 \pm 0.80 \mathrm{mg} / \mathrm{dL}$; total protein as $5.71 \pm 0.21$, $5.10 \pm 0.15 \mathrm{~g} / \mathrm{dL}$; albumin as $3.74 \pm 0.06,3.71 \pm 0.12 \mathrm{~g} / \mathrm{dL}$; urea as $20.08 \pm 1.14,25.37 \pm 1.74 \mathrm{mg} / \mathrm{dL}$; cholesteol as $35.75 \pm 3.41$, $28.05 \pm 1.41 \mathrm{mg} / \mathrm{dL}$; triglycerides as $28.27 \pm 1.32,48.44 \pm 2.75$ $\mathrm{mg} / \mathrm{dL}$; calcium as $10.94 \pm 0.26,11.11 \pm 0.48 \mathrm{mg} / \mathrm{dL}$ and phosphorus as $8.66 \pm 0.41,6.95 \pm 0.58 \mathrm{mg} / \mathrm{dL}$ in weaned calves at 6 and 9 months age, respectively. Present findings are in agreement with the findings of Farooq et al. (2011) who studied the normal reference hematological concentration of one-humped camels in Cholistan desert and reported the range for hemoglobin as 7-17 and 8-17 g/dL in male and females, respectively.

Economic analysis: IMS has lower cost due to the reason that higher growth rate was achieved in calves as they receive concentrate supplementation, confined in area having shades that reduced stress and there was free choice of feeding. However, the calves in SIMS were on grazing mostly in hotter parts of the day influencing by stress of exercise, watering and heat. Moreover, weather conditions were also affected on grazing/browsing species growth. So, the IMS group was found to be more economical than SIMS.

Conclusion: The findings of present study indicated that higher growth rate was achieved in IMS than SIMS. Moreover, male claves were found to be heavier than female calves in both management systems. The biometrical parameters and blood biochemistry also confirmed the results. IMS was found to be economical than SIMS. It is concluded that Pakistani camel calves have great production potential that could be exploited by modern husbandry practices according to scientific lines. So it will be a useful addition to the food chain.

Acknowledgements: We gratefully acknowledge the support of management of Camel Breeding and Research Station (CBRS) Rakh Mahni, Tahsil Mankera District Bhakkar and financial support of Higher Education Commission (HEC) Islamabad, Pakistan for this study.

\section{REFERENCES}

Al-Busadah, K.A. and T.E.A. Osman. 2000. Haematological parameters of adult dry, lactating and camel calves in Saudi Arabia. Pak. J. Biol. Sci. 3:1749-1751.

AOAC. 1990. Official Methods of Analysis, 15 ${ }^{\text {th }}$ Ed. Vol. 1. Association of Official Analytical Chemists, Virginia, USA.

Bakheit, S.A., A. Idris, B. Faye and O. Abdelhadi. 2012. The effect of management system on camel's milk yield and calve growth rate in North Kordofan, Sudan. Conf. Int. Res. on Food Security, Natural Resource Management 
and Rural Development, 19-21 Sep. Tropentag, Gottingen, Germany.

Bhakat, C., N. Saini and K.M.L. Pathak. 2008. Effect of management systems on the performance of dromedary camel calves reared under organized farm condition. Ind. J. Anim. Sci. 78:1023-1027.

Bhakat, C., N. Saini and K.M.L. Pathak. 2009. Growth characteristics, economics and hair mineral status of camel calves reared in different systems of management. Ind. J. Anim. Sci. 79:932-935.

Brar, R.S., H.S. Sandhu and A. Singh. 2000. Veterinary Clinical Diagnosis by Laboratory Methods. Kalyani Publishers, India.

Farooq, U., H.A. Samad, A. Khurshid and S. Sajjad. 2011. Normal reference hematological values of one-humped camels (Camelus dromedarius) kept in Cholistan desert. J. Anim. Plant Sci. 21:157-160.

Faye, B. and P. Esenov. 2005. Desertification Combat and Food Safety: The added value of camel producers. IOS Press, Amsterdam.

Hossner, K.L. 2005. Hormonal Regulation of Farm Animal Growth. CABI Publishing, 875 Massachusetts Avenue, $7^{\text {th }}$ Floor, MA 02139, Cambridge, USA.

Iqbal, A., R.A. Gill and M. Younas. 2001. Milk composition of Pakistani camel (Camelus dromedaries) kept under station/farmer's conditions. Emir. J. Agric. Sci. 13:7-10.

Khanna, N.D., A.K. Rai and S.N. Tandon. 2004. Camel breeds of India. The Camel Applied Research and Development Network (CARDN). J. Camel Sci. 1:8-15.

Knoess, K.H. 1977. The camel as a meat and milk animal. World Anim. Rev. 22:39-42.

Kurtu, M.Y. 2004. An assessment of the productivity for meat and carcass yield of camels (Camelus dromedarius) and of the consumption of camel meat in the eastern region of Ethiopia. Trop. Anim. Health Prod. 36:65-76.

Mohamedain, N.M., I.M.T. Fadlalla, M.E. Barri and B.E. Abdel-Aziz. 2015. Growth performance in dromedary camels under two feeding regimen. The Regional Conference of Camel Management and Production under Open Range System (RCCMPR), March 2-4, KhartoumSudan.

Murphy, W.G. 2014. The sex difference in haemoglobin levels in adults - Mechanisms, causes, and consequences. Blood Reviews, Available online at http://dx.doi.org/10.1016/j.blre.2013.12.003

Musavaya, K. 2003. Weight development in camels of different age and sex classes under field conditions in a semi-arid area in northern Kenya. Master Thesis, available online at http//www.troz.unihohenheim.de/research/Thesis/MScAP

Nagpal, A.K., G.P. Singh, U.K. Bissa and N. Sharma. 2012. Voluntary feed intake, serum profile, growth performance and economics of weaned camel calves. J. Camel Prac. Res. 19:283-285.
Omer, S.A., H. Agab, G.H.A. Samad and I.Y. Turki. 2008. Effect of feed type on some blood constituents of Sudanese growing camel (Camelus dromedarius) calves. Sud. J. Vet. Sci. Anim. Husb. 47:107-115.

Osman, T.E.A. and K.A. Al-Busadah. 2000. Effects of age and lactation on some biochemical constituents of camel blood in Saudi Arabia. J. Camel Prac. Res. 7:149-152.

Osman, T.E.A. and K.A. Al-Busadah. 2003. Normal concentrations of twenty serum biochemical parameters of she-camels, cows and ewes in Saudi Arabia. Pak. J. Biol. Sci. 6:1253-1256.

Qureshi, M.H. 1986. The camel. A paper presented at a seminar on the camel, Kuwait; Oct 20-23, FAO, Rome; pp.1-35.

Rahim, S.M.A., S. Hasnain and J. Farkhanda. 2011. Effect of calcium, magnesium, sodium and potassium on farm plantations of various agroecological zones of Punjab, Pakistan. Afr. J. Plant Sci. 5:450-459.

Sahani, M.S., U.K. Bissa and N.D. Khanna. 1998. Factors influencing pre and post weaning body weights and daily weight gain in indigenous breeds of camels under farm conditions. Proc. $3^{\text {rd }}$ Ann. Meeting for Animal Production under Arid Conditions, UAE University; 1: 59-64.

Saini, N., B.D. Kiradoo and D.L. Bohra. 2014. Impact of feeding on growth performance, blood biochemical and mineral profiles of pre-pubescent camels under pastoral management in arid western Rajasthan. Trop. Anim. Health Prod. 46:987-994.

Schroeder, J.W. 2013. Forage Nutrition for Ruminants: Quality forage. NDSU Extension Service, AS1250 (Revised); pp.1-16.

Schwartz, H.J., M. Dioli, R. Stimmelmayr and M.G.H. Walsh. 1992. The one-humped camel (Camelus dromedarius) in eastern Africa: A pictorial guide to diseases, health care and management. Verlag Josef Margraf Scientific Books, Weikersheim, Germany.

Singh, G.P., A.K. Nagpal, N. Saini and P. Jayant. 2000. Studies on feed requirement and feed resources evaluation for optimum production. Annual Report, NRCC, Bikaner; pp.26-34.

SPSS. 2008. SPSS Statistics for Windows, Version 17.0. Chicago: SPSS Inc. Chicago, IL., USA.

Steel, R.G.D., J.H. Torrie and D.A. Dicky. 1997. Principles and Procedures of Statistics: A biometric approach, $3^{\text {rd }}$ Ed. McGraw Hill Book Co., New York, USA.

Tandon, S.N., N.D. Khanna and N. Sharma. 1993. To develop suitable management practices for rearing camels. Annual Report, NRCC, Bikaner; pp. 45-49.

Van Soest, P.J., J.B. Robertson and B.A. Lewis. 1991. Method for dietary fiber, neutral detergent fiber, and nonstarch polysaccharides in relation to animal nutrition. J. Dairy Sci. 74:3583-3597.

Wilson, R.T. 1998. Camels. The Tropical Agriculturalist series. McMillan Education Ltd. London, UK. 